\title{
Promising breeding material of winter triticale in the conditions of the Middle Urals
}

\author{
G.N. Potapova ${ }^{1, *}$, N.N. Zezin ${ }^{1}$, N.L. Zobnina ${ }^{1}$, and M.S. Ivanova ${ }^{2}$ \\ ${ }^{1}$ Ural Scientific Research Institute of Agriculture - branch of the Ural Federal Agrarian Research \\ Center of the Ural Branch of the Russian Academy of Sciences, 620142, Sverdlovsk region, Belinsky \\ Str., 112-a, Yekaterinburg, Russia \\ ${ }^{2}$ Ural State Agrarian University, 620075, K. Liebknecht Str., 42, Yekaterinburg, Russia
}

\begin{abstract}
The research was carried out in 2012-2018 in test sowings of the Ural Agricultural Research Institute- branch of the FSBSI Ural Federal Agrarian Research Center of the Ural Branch of the Russian Academy of Sciences with the aim to obtain promising high-yielding, locally adapted breeding samples of winter triticale. We used interverietal hybridization and evaluation of hybrids $\mathrm{F}_{1}-\mathrm{F}_{4}$, selection and sowing of ears and plants in breeding nurseries. Evaluation of promising lines on plots of $5-10 \mathrm{~m}^{2}$ according to generally accepted methods. Breeding samples of winter triticale were obtained, the yield of which reached 6.8-7.0 t/ha and was 15$19 \%$ higher than the standard - Bashkirskaya korotkostevelnaya (5.9 t/ha). The winter hardiness of the best samples was at the level of $80-90 \%$ and exceeded the standard $(72 \%)$ by $12-18 \%$. Samples were found that exceeded the standard by the number of grains in the ear, the weight of 1000 grains, the ear productivity and the content of raw protein in the grain. The selected hybrid samples are evaluated in a competitive test and propagated in isolated areas.
\end{abstract}

\section{Introduction}

Winter triticale has been grown in the southern regions of the Russian Federation for more than 50 years, as it has a lower winter hardiness than winter rye [1]. Under favorable growing conditions, winter triticale varieties can form a grain yield of up to 7-10 t/ha [2], containing up to $15 \%$ protein, which is consistent with modern trends in the breeding of new varieties of plant crops with an increased content of nutrients $[3,4]$. Tall-growing forage varieties allow to obtain up to $60 \mathrm{t} / \mathrm{ha}$ of green mass [5]. Due to climate change, triticale crops are shifting to the northern regions of Russia. For about 15 years, winter triticale varieties created in other regions of Russia have been grown in the Middle Urals, which are not sufficiently adapted to local weather conditions and their sowings partially or completely die in winter. In local conditions, they are not able to realize a high productive potential, so the average grain yield in the Sverdlovsk region does not exceed $2 \mathrm{t} / \mathrm{ha}$ [6]. Due to the fact that previously the selection of winter triticale was not carried out in local conditions, the creation of a new breeding material for obtaining new adaptive and highly

\footnotetext{
* Corresponding author: gnp6053@list.ru
} 
productive varieties is relevant. Intervarietal hybridization with subsequent selection of highly productive lines is one of the ways to combine the characteristic features of locally isolated varieties in one genotype [7]. The purpose of the research is to obtain a new highly productive breeding material of winter triticale, adapted to the agro-climatic conditions of the Middle Urals, promising for the creation of new highly productive varieties.

\section{Material and methods}

The research was carried out in 2012-2018 in test sowings of the Ural Agricultural Research Institute- branch of the FSBSI Ural Federal Agrarian Research Center of the Ural Branch of the Russian Academy of Sciences in accordance with the thematic task "Development and improvement of breeding work methods, creation of source material and adaptive varieties of cereals, legumes, fodder, fruit and berry, ornamental crops and potatoes (0773-2019-0023-S-01).

Hybridization was carried out by castration of 5-10 ears of maternal plants with further substitution of paternal ears under a parchment insulator. Each year, 25-60 hybrid grains were obtained from 8-10 crossing combinations. In the $F_{1}$ nurseries, seeds were sown manually in $1-2$ rows $1 \mathrm{~m}$ long, located $15 \mathrm{~cm}$ apart. During the growing season, observations were carried out, during harvesting, the plants were removed with roots. After evaluation of the number of plants, productive stems, plant height and crop structure elements, plants were selected for sowing. Sowing of hybrids $F_{2}$ and $F_{3}$ was carried out manually on plotsof $1 \mathrm{~m}^{2}$ with a seeding rate of $150-200$ grains per $1 \mathrm{~m}^{2}$ in 3-4 repetitions. The selection of ears and plants was carried out in generations $\mathrm{F}_{3}$ and $\mathrm{F}_{4}$. In the breeding nursery of the 1st year, un-threshed ears and seeds from threshed ears were sown with the number of grains from 55 pieces and the weight of 1000 grains from $40 \mathrm{~g}$. The best lines were selected according to the yield exceeding the average for the nursery by 10 percent or more. For evaluation in the breeding nursery of the third year, sowing was carried out with a SFK seeder on plots of $5-10 \mathrm{~m}^{2}$ in 3-4 repetitions. The standard Bashkirskaya korotkostebelnaya variety was placed every 9 plots.

The experiments were placed in a three-field crop rotation on dead fallow, which was preceded by pea sowings for seeds. The soil of the experimental site is dark gray forest, podzolized, heavy loamy, with a humus content of $4.0 \%, \mathrm{pH} 4.8$, nitrogen $87 \mathrm{mg} / \mathrm{kg}$ of soil, phosphorus and potassium $107 \mathrm{mg} / \mathrm{kg}$ and $85 \mathrm{mg} / \mathrm{kg}$ of soil, respectively. Before sowing, azophoska was introduced at the rate of $2 \mathrm{c} / \mathrm{ha}$, or $32 \mathrm{~kg} / \mathrm{ha}$ of nitrogen, phosphorus and potassium. In the spring, $1 \mathrm{c} /$ ha of ammonium nitrate with a total nitrogen content of $34.4 \%$ was introduced for fertilizing. Observations and evaluations were carried out according to generally accepted methods $[8,9]$.

Weather conditions during the years of research varied significantly, which allowed to evaluate and select a promising hybrid breeding material. The winters were warm, with a lack of precipitation in 2015 and 2018, with an excess of precipitation in 2013, 2014,2016, 2017. The summer was cool with an excess of precipitation in 2014, hot and dry in 2016.

\section{Results and discussion}

The number of hybrid grains that were sown in the first year in the $F_{1}$ nursery differed, therefore, for most indicators, the differences were significant and unreliable. In generations $\mathrm{F}_{2}$ and $\mathrm{F}_{3}$, plant differences in height, color of the seta and ear were often observed. The selection of ears and plants was carried out in $\mathrm{F}_{3}$ and $\mathrm{F}_{4}$.

As a result of the study in nurseries $F_{2}-F_{3}$, hybrid samples were identified, on average, exceeding the Bashkirskaya korotkostebelnaya standard over the years of study, or not 
inferior to it in yield, and showed advantages in individual elements of the yield structure. In 2013, in the $F_{2}$ nursery, the yield of many hybrid samples was below the standard (622 $\mathrm{g} / \mathrm{m}^{2}$ ). A significant excess to the standard for yield by 17 and $28 \%$ was shown by the samples of Sirs 57 x Cornet and Tsekad 90 x Bashkirskaya korotkostebelnaya, respectively (Table 1). In the samples of Sirs $57 \mathrm{x}$ Bard and Cornet $\mathrm{x}$, the Bashkirskaya korotkostebelnaya yield was at the standard level or slightly higher.

In 2014, the yield of seven hybrid samples reached $638-755 \mathrm{~g} / \mathrm{m}^{2}$ and was significantly higher than the standard by $25-47 \%$. With a yield level of $628-672 \mathrm{~g} / \mathrm{m}^{2}$, the samples of Talva 100 x Zimogor, Sirs 57 x Cornet, Tsekad 90 x Bashkirskaya korotkostebelnaya and Zimogor $\mathrm{x}$ Tsekad 90 significantly exceeded the standard for two years of study by 11$18 \%$. In six samples, the yield was at the standard level $\left(513-621 \mathrm{~g} / \mathrm{m}^{2}\right)$. The samples of Sirs $57 \mathrm{x}$ Bard and Bard x Sirs 57 had a slight excess to the yield standard in one of the two years of study, but they had a large ear, on average 10.5-11.6 cm long, with a grain count of more than 60 pieces and weight of 1000 grains of 43.8 and $45.6 \mathrm{~g}$.

The winter hardiness of the samples with high yield was higher than the standard for an average of two years, the height of the plants ranged from 80 to $110 \mathrm{~cm}$, the resistance to lodging was high, so they were included in the group of promising winter triticale varieties for obtaining new high-yielding grain varieties.

Table 1. Characteristics of the best hybrids $\mathrm{F}_{2}$ and $\mathrm{F}_{3}$ of winter triticale by economic and valuable traits (2013 and 2014).

\begin{tabular}{|c|c|c|c|c|c|c|c|c|c|}
\hline \multirow[b]{2}{*}{ Sample } & \multicolumn{3}{|c|}{ Yield, $\mathrm{g} / \mathrm{m}^{2}$} & \multirow[b]{2}{*}{$\begin{array}{c}\text { Winter } \\
\text { hardiness, \% }\end{array}$} & \multirow[b]{2}{*}{$\begin{array}{l}\text { Heigh } \\
\mathrm{t}, \mathrm{cm}\end{array}$} & \multirow{2}{*}{$\begin{array}{l}\text { Resistan } \\
\text { ce to } \\
\text { lodging, } \\
\text { point }\end{array}$} & \multirow{2}{*}{$\begin{array}{c}\text { Density of } \\
\text { productive } \\
\text { stems, } \\
\text { pcs. } / \mathrm{m}^{2}\end{array}$} & \multirow{2}{*}{$\begin{array}{l}\text { Productive } \\
\text { tilling } \\
\text { capacity, } \\
\text { stems/plant }\end{array}$} & \multirow{2}{*}{$\begin{array}{c}\text { Weight } \\
\text { of } 1000 \\
\text { grains, } \\
\mathrm{g}\end{array}$} \\
\hline & $\mathrm{F}_{2}$ & $\mathrm{~F}_{3}$ & average & & & & & & \\
\hline $\begin{array}{l}\text { Bashkirskaya } \\
\text { korotkostebelnaya }\end{array}$ & 622 & 512 & 567 & 70 & 102 & 9 & 328 & 3.6 & 36.4 \\
\hline Zimogor x Tsekad 90 & $\begin{array}{c}556 \\
*\end{array}$ & $714^{*}$ & $635^{*}$ & $87^{*}$ & 95 & 9 & $394^{*}$ & $4.4^{*}$ & 36.7 \\
\hline $\begin{array}{ll}\text { Zimogor } & \mathrm{x} \\
\text { Bashkirskaya } & \\
\text { korotkostebelnaya } & \\
\end{array}$ & 579 & $657^{*}$ & 618 & 82 & 93 & 9 & 264 & 3.2 & 40.5 \\
\hline Talva $100 \times$ Zimogor & $\begin{array}{c}504 \\
*\end{array}$ & $755^{*}$ & $640^{*}$ & $91^{*}$ & 98 & 8 & 285 & 3.5 & 38.1 \\
\hline $\begin{array}{ll}\text { Talva } 100 & \mathrm{x} \\
\text { Bashkirskaya } & \\
\text { korotkostebelnaya } & \\
\end{array}$ & 594 & 528 & 561 & $90^{*}$ & 98 & 7 & 285 & $4.9^{*}$ & 36.2 \\
\hline Talva 100 x Sirs 57 & $\begin{array}{c}532 \\
*\end{array}$ & $642^{*}$ & 587 & $96^{*}$ & 107 & 8 & 358 & 3.8 & $46.3^{*}$ \\
\hline Sirs $57 \times$ Cornet & $\begin{array}{c}727 \\
*\end{array}$ & $638^{*}$ & $672^{*}$ & $86^{*}$ & 100 & 9 & $421 *$ & 3.3 & 40.4 \\
\hline Sirs $57 \times$ Bard & 694 & 463 & 512 & $94^{*}$ & 101 & 9 & $362 *$ & 3.8 & $45.6^{*}$ \\
\hline $\begin{array}{ll}\text { Tsekad } 90 & \mathrm{x} \\
\text { Bashkirskaya } & \\
\text { korotkostebelnaya } & \\
\end{array}$ & $\begin{array}{c}797 \\
*\end{array}$ & $664^{*}$ & $628^{*}$ & $90^{*}$ & 105 & 9 & 345 & 3.8 & 35.5 \\
\hline $\begin{array}{l}\text { Cornet x Bashkirskaya } \\
\text { korotkostebelnaya }\end{array}$ & 622 & 446 & 534 & $97^{*}$ & 109 & 9 & 240 & 3.0 & $47.4^{*}$ \\
\hline $\begin{array}{l}\text { Tornado x Bashkirskya } \\
1\end{array}$ & 445 & 416 & 430 & 82 & 149 & 5 & $372 *$ & 3.5 & $50.3 *$ \\
\hline LSD05 & 68 & 51 & 54 & 8 & & & 32 & 0.4 & 4.1 \\
\hline
\end{tabular}

* Significantly higher or lower than the standard for $\mathrm{LSD}_{05}$.

The samples of Zimogor x Tsekad 90, Sirs 57 x Bard and Sirs 57 x Cornet had a density of productive stem significantly higher than the standard by $10-28 \%$. In the sample of Zimogor $\mathrm{x}$ Tsekad 90 , the productive tilling capacity exceeded the standard by $22 \%$ with an equal number of plants. In the Talva $100 \mathrm{x}$ Bashkirskaya korotkostebelnaya productive tilling capacity was higher than the standard $36 \%$, but the density of plants and productive stems was lower.

The grain yield of the Tornado x Bashkirskaya 1 sample was lower than the standard, but the plant height reached $150 \mathrm{~cm}$, the density of the productive stem, the weight of 1000 grains $(50.3 \mathrm{~g})$ and the increased protein content in the grain (13.6-15.2\%) were higher than 
the standard. This sample was recognized as promising for obtaining a tall-growing forage variety.

In 2013 and 2014, ears and plants were selected in hybrid nurseries $\mathrm{F}_{3}$ and $\mathrm{F}_{4}$, which were sown in breeding nurseries SP-1. In 2013, 150-200 unfilled ears were sown from 13 hybrid samples with a feeding area of $60 \times 40 \mathrm{~cm}$, of which in 2014, after harvesting with a sickle and analysis, families of hybrid samples were left to work, the productivity of which was $10-43 \%$ higher than the average for the sample (table 2).

Table 2. Characteristics of productivity of families selected in the breeding nursery after sowing of ears.

\begin{tabular}{|l|c|c|c|c|c|}
\hline Hybrid & Harvested & \multicolumn{2}{l|}{ Productivity, g/family } & Selected \\
& families & $\begin{array}{l}\text { averag } \\
\text { f }\end{array}$ & best & \% to average & \\
\hline \multicolumn{7}{|c|}{ Sowing with unthreshed ears, 2014 } \\
\hline Zimogor x Tsekad 90 & 124 & 83 & $99-119$ & $110-143$ & 14 \\
\hline $\begin{array}{l}\text { Tsekad 90 x Bashkirskaya } \\
\text { korotkostebelnaya }\end{array}$ & 114 & 103 & $121-132$ & $117-128$ & 21 \\
\hline Talva 100 x Zimogor & 112 & 47 & $56-74$ & $118-158$ & 5 \\
\hline Tornado x Bashkirskaya 1 & 42 & 102 & $115-126$ & $113-124$ & 6 \\
\hline \multicolumn{7}{|c|}{ Sowing after threshing of ears, 2015 } \\
\hline Talva 100 x Zimogor & 62 & 198 & $218-276$ & $110-139$ & 11 \\
\hline Zimogor x Tsekad 90 & 51 & 271 & $303-387$ & $112-143$ & 10 \\
\hline Tornado x Bashkirskaya 1 & 46 & 273 & $306-379$ & $112-139$ & 11 \\
\hline
\end{tabular}

In the future, they began to sow the seeds of threshed ears. For sowing, the ears of one plant with a number of grains of more than 55 pieces and a weight of 1000 grains above 40 $\mathrm{g}$ were selected. Seeds from one ear were sown manually on 2 rows $1 \mathrm{~m}$ long every $15 \mathrm{~cm}$. The ears from one plant were sown in a separate block. As a result, the evaluation was carried out on the offspring from the ear and the plant. The breeding nursery, after sowing seeds from threshed ears, occupied a much smaller area, was not overgrown with weeds, which contributed to a significant reduction in labor costs. The conditions for plant development were better, so the productivity of the line increased almost twice (see Table 2). For harvesting, lines were selected that were even in height, with a large ear, resistant to lodging, without signs of disease damage. They were harvested with a sickle, threshed on a sheaf thresher, the productivity of the selected lines, the weight of 1000 grains and the productivity of the ear were determined.

The seeds of the best winter hardiness and productivity lines were sown on plots of 5-10 $\mathrm{m}^{2}$ in the breeding nursery 3. The results presented in Table 3 showed that in 2016 the yield of the best breeding samples was higher than $6 \mathrm{t} / \mathrm{ha}$ and exceeded the Bashkirskaya korotkostebelnaya standard by 11-22\%.

The yield of the selected winter triticale lines ranged from 6 to 7 tha and was significantly higher than the standard by $19-24 \%$. The winter hardiness of the best hybrid lines significantly exceeded the standard by $12-18 \%$. 
Table 3. Characteristics of promising winter triticale lines obtained in the conditions of the Middle Urals (2016-2017)

\begin{tabular}{|c|c|c|c|c|c|c|c|c|c|}
\hline \multirow{2}{*}{ Name } & \multicolumn{3}{|c|}{ Yield, t/ha } & \multirow{2}{*}{$\begin{array}{c}\text { Winter } \\
\text { hardiness } \\
, \%\end{array}$} & \multirow{2}{*}{$\begin{array}{c}\text { Height, } \\
\mathrm{cm}\end{array}$} & \multirow{2}{*}{$\begin{array}{l}\text { Grains } \\
\text { per ear, } \\
\text { pcs. }\end{array}$} & \multirow{2}{*}{$\begin{array}{l}\text { Weight } \\
\text { of } 1000 \\
\text { grains, } g\end{array}$} & \multirow{2}{*}{$\begin{array}{l}\text { Ear } \\
\text { produc } \\
\text { tivity, } \\
\text { g }\end{array}$} & \multirow{2}{*}{$\begin{array}{l}\text { Crud } \\
\mathrm{e} \\
\text { prote } \\
\text { in, } \%\end{array}$} \\
\hline & 2016 & 2017 & average & & & & & & \\
\hline $\begin{array}{l}\text { Bashkirskaya } \\
\text { korotkostebelnaya, } \\
\text { st. }\end{array}$ & 5.66 & 6.18 & 5.92 & 72 & 104 & 47.3 & 36.9 & 1.74 & 12.5 \\
\hline $\begin{array}{l}\text { Zimogor } \mathrm{x} \text { Tsekad } \\
90\end{array}$ & $6.88^{*}$ & $7.15^{*}$ & $7.01^{*}$ & 84 & 86 & $56.2^{*}$ & 35.4 & $1.99^{*}$ & $14.4^{*}$ \\
\hline $\begin{array}{ll}\text { Tsekad } 90 & \mathrm{x} \\
\text { Bashkirskaya } & \\
\text { korotkostebelnaya } & \end{array}$ & $6.67^{*}$ & $7.98^{*}$ & $7.35^{*}$ & $90^{*}$ & 105 & 48.4 & 36.7 & 1.78 & 13.2 \\
\hline Talva 100 x Zimogor & $6.49 *$ & $7.55^{*}$ & $7.02 *$ & $94 *$ & 97 & $54.8^{*}$ & $42.6^{*}$ & $2.33^{*}$ & 12.6 \\
\hline $\begin{array}{ll}\text { Zimogor } & \mathrm{x} \\
\text { Bashkirskaya } & \\
\text { korotkostebelnaya } & \end{array}$ & $6.57^{*}$ & $7.07^{*}$ & $6.82 *$ & 85 & 88 & 49.5 & 40.5 & $2.00^{*}$ & 13.1 \\
\hline $\begin{array}{ll}\text { Tornado } & \mathrm{x} \\
\text { Bashkirskaya 1 } & \\
\end{array}$ & 6.30 & 4.16 & 5.23 & $90^{*}$ & $148^{*}$ & 44.6 & $42.3^{*}$ & 1.89 & 13.6 \\
\hline $\mathrm{LSD}_{05}$ & 0.51 & 0.63 & 0.58 & 8.1 & 12.4 & 4.9 & 3.8 & 0.20 & 1.1 \\
\hline
\end{tabular}

In 2017, the grain yield of short-stemmed breeding samples was at the level of 7.07$7.98 \mathrm{t} / \mathrm{ha}$ and was $14-29 \%$ higher than the standard. On average, for two years, the yield of short-stemmed samples was 6.82-7.35 t/ha and was higher than the standard by $0.9-1.43$ $\mathrm{t} / \mathrm{ha}$ or $15-24 \%$. This indicates a high productive potential of the obtained breeding samples of winter triticale. On average, the winter hardiness of these samples was at the level of 84$94 \%$ for two years. The winter hardiness was significantly higher than the standard by 18 $22 \%$ in the samplesTsekad $90 \times$ Bashkirskaya korotkostebelnaya and Talva $100 \times$ Zimogor. In the samples of Zimogor $\mathrm{x}$ Tsekad 90 and Talva $100 \mathrm{x}$ Zimogor, the number of grains in the ear was 16-19\% higher than the standard. The samples have Talva $100 \times$ Zimogor andTornado x Bashkirskaya 1 the weight of 1000 grains was $15 \%$ higher than the standard. The productivity of the ear in the samples Zimogor x Tsekad 90, Talva $100 \times$ Zimogor and Zimogor x Bashkirskaya korotkostebelnaya was higher than the standard by 14-34\%. The content of crude protein in the grain of the selected samples was at the standard level, or slightly higher. According to the protein content in the grain, the samples of Zimogor $x$ Tsekad 90 andTornado x Bashkirskaya 1 significantly exceeded the standard by $9-15 \%$.

\section{Conclusions}

In the course of breeding work, samples of winter triticale were obtained, the yield of which reached an average of $6.8-7.0 \mathrm{t} / \mathrm{ha}$ in two years and was $15-19 \%$ higher than the Bashkirskaya korotkostebelnaya standard (5.9 t/ha). The winter hardiness of the best samples was at the level of $80-90 \%$ and exceeded the standard (72\%) by $12-18 \%$. Samples were found that exceeded the standard by the number of grains in the ear, the weight of 1000 grains, the ear productivity and the content of raw protein in the grain. The selected hybrid samples are evaluated in a competitive test and propagated in isolated areas. 


\section{References}

1. S.I. Fomin, S.N. Ponomarev, M.L. Ponomareva, G. S. Mannapova, L. V. Ilalova, L. F. Gilmullina, Agriculture 3, 44-47 (2019)

2. A. M. Medvedev, N.G. Poma, V. V. Osipov, A. V. Osipova, E. N. Liseenko, I. N. Serebrennikova, Legumes and cereals 1 (29), 89-93 (2019)

3. Igor G. Loskutov, Elena K. Khlestkina, Wheat, PLANTS 10(1), 86 (2021) DOI:10.3390/plants10010086

4. S.I. Zoran, Agricultural and Forestry 65 (4), 127-136 (2019)

5. T.A. Goryanina, Feed production 6, 23-27 (2019)

6. N.N. Zezin, Scientifically based zonal system of agriculture of the Sverdlovsk region. (Under the general editorship of Doctor of Agricultural Sciences N.N. Zezin), 16-20 (Yekaterinburg, Pub: "UroRAN", 2020)

7. A.M. Medvedev, S.I. Voronov, A.V. Nardid, T.A. Goryanina, Legumes and cereals 1 (33), 82-87 (2020)

8. A.F. Merezhko, Replenishment, preservation in a live form and study of the world collection of wheat, aegilops and triticale. Method. instructions of VIR, 61 (St. Petersburg, 1997)

9. M.A. Fedin, Methods of state variety testing of agricultural crops, 263 (Moscow, 1985) 